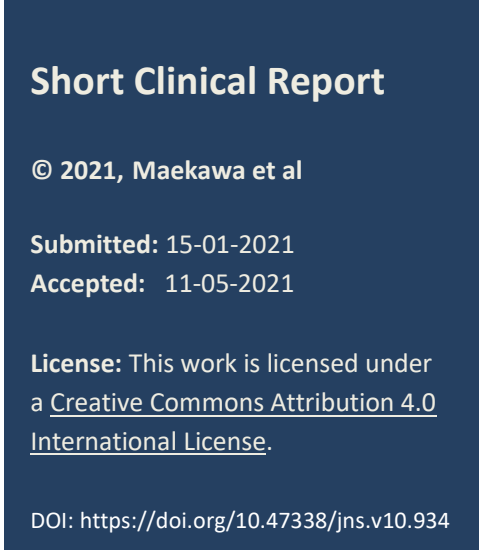

\section{A case of hernia of the umbilical cord with an accessory liver}

Shohei Maekawa, ${ }^{*}$ Shuhei Kogata, Takashi Sasaki

Division of Pediatric Surgery, Department of Surgery, Kindai University Faculty of Medicine, Japan.

Correspondence*: Shohei Maekawa, Division of Pediatric Surgery, Department of Surgery, Kindai University Faculty of Medicine, Japan. E-mail: shohei@med.kindai.ac.jp

\section{CASE PRESENTATION}

A female neonate was born at 38 weeks, 4 days gestation via normal vaginal delivery with a birth weight of $2.984 \mathrm{~kg}$; both 1 - and 5-min APGAR scores were 9. She had been suspected of having a small omphalocele with an umbilical cord cyst on prenatal ultrasound at 25 weeks of gestation. Repeated ultrasonography every two weeks did not change the findings of umbilical cord cysts and small omphalocele. After birth, her umbilical cord base was $20 \mathrm{~mm}$ in diameter, with an elastic rigid tumor-like structure instead of an umbilical cord (Fig.1A), and a definitive diagnosis of hernia of the umbilical cord with accessory liver was confirmed following computed tomography scan (Fig. 1B).

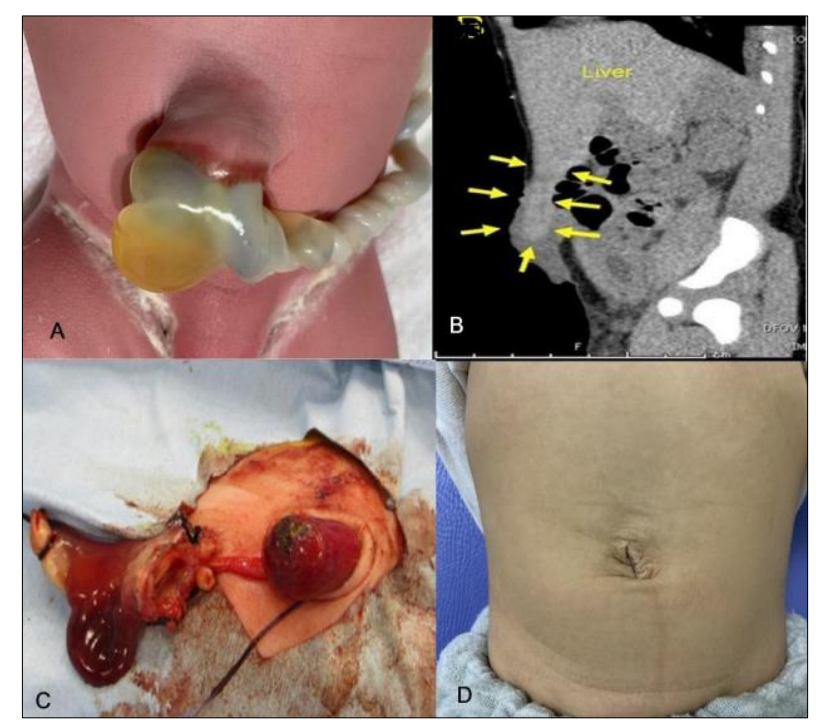

Figure 1: A) Pre-operative picture showing hernia of umbilical cord. B) CT scan showing accessory liver herniating through abdominal wall defect (Arrows). C) Peroperative figure showing dissected accessory liver tissue. D) Follow up after one year of umbilicoplasty.

As the herniation was not reducible. Blood examination after birth showed AST/ALT 394/10U/L, LDH
$1291 \mathrm{U} / \mathrm{L}$, and CK $610 \mathrm{U} / \mathrm{L}$, there was a possibility of reduced blood flow to the liver. Her postnatal condition was stable, she was operated on the day of her birth. After making a circular skin incision around the umbilical cord and a longitudinal opening of the linea alba, the round ligament of the liver and medial and lateral umbilical ligaments were ligated and cut simultaneously, and the abdominal cavity was accessed. The accessory liver protruded from the edge of the lateral segment of the liver and firmly adhered to the umbilical cord. It was approximately $15 \mathrm{~mm}$ in size and appeared congestive and dark red compared to the main liver. Immediately after a careful adhesiolysis using an electric cautery, the invaginated tissue was restored to its normal condition and then preserved and returned into the abdominal cavity (Fig.1C). The postoperative course was uneventful, without signs of torsion of the accessory liver. Currently, the patient is a 1-year-old healthy girl with a satisfactory navel appearance (Fig.1D).

\section{DISCUSSION}

Hernia of the umbilical cord (HUC) is a failure of the umbilical ring's morphogenesis that occurs around 4 weeks of gestation, it is thought to develop due to abnormalities in the reducing process of physiological umbilical herniation at $\geq 10$ weeks of gestation.[1-3] Glenisson et al. recommended classifying accessory liver defects according to their morphological presentation: A) hepatic parenchymal tissue is interposed between the hepatic parenchymal and primary liver tissue, B) the main liver organ and hepatic parenchymal tissue are connected by a peduncle, and C) the hepatic parenchymal tissue mass is completely separated from the liver.[4] Our case met type A according to this classification.

A review of the literature revealed that the number of HUC cases with an accessory liver is small.[1-3,6,7] Consistent with our findings, the firmly adhered accessory liver to the hernial sac of the umbilical cord 
has been reported previously. This finding might suggest morphogenetic involvement of the adhesion in the liver bud to the umbilical coelom because the liver bud and umbilical cord are very close to each other at around 4 weeks of gestation when the umbilical ring begins to form. In early reports, the accessory liver had been aggressively resected $[1,5]$ although it has been avoided in recent reports.[2,3,6] According to descriptions of the torsion of the accessory liver,[7] the accessory liver's size is unlikely to develop a torsion. Thus, considering the risk of sequelae such as bleeding from the cut surface and post-surgical adhesion, preserving the invaginated accessory liver and

\section{REFERENCES}

1. Ito $\mathrm{F}$, Ando $\mathrm{H}$, Watanabe $\mathrm{Y}$, Seo $\mathrm{T}$, Murahashi $\mathrm{O}$, Harada $\mathrm{T}$, et al. An accessory lobe of the liver disturbing closure of the umbilical ring. Pediatr Surg Int. 1999; 15:394-6.

2. Zameer MM, Mahalik S, Kanojia R, Rao KL. Entire liver as the only content of hernia of the umbilical cord. Hernia. 2012; 16:605-6.

3. Boybeyi Ö, Ozmen I, Gunal YD, Aslan MK, Aliefendioglu D. Caudate lobe of the liver as the only content of the umbilical cord hernia. Congenit Anom. 2015; 55:170.

4. Glenisson M, Salloum C, Lim C, Lacaze L, Malek A, Enriquez A, et al. Accessory liver lobes: anatomical leaving it in the abdominal cavity would be the best choice.

\section{Acknowledgements: Nil}

Conflict of Interest: None declared

Source of Support: Nil

Consent to Publication: Author(s) declared taking informed written consent for the publication of clinical photographs/material (if any used), from the legal guardian of the patient with an understanding that every effort will be made to conceal the identity of the patient, however it cannot be guaranteed.

Author Contributions: Author(s) declared to fulfil authorship criteria as devised by ICMJE and approved the final version. description and clinical implications. J Visc Surg. 2014; 151:451-5.

5. Festen C, Severijnen RS, vd Staak FH. Gallbladder embedded in an accessory liver lobe in umbilical cord hernia. J Pediatr Surg. 1988; 23:978-9.

6. Hasaniya NW, Premaratne S, Varnes PM, Shin D, Shim W. Hernia into the umbilical cord with the incarceration of liver and gallbladder in a newborn. J Pediatr Surg Case Rep. 2013; 432-3.

7. Pérez-Martínez A, Conde-Cortés J, Martínez-Bermejo MA, Bento-Bravo L. Torsion of a pedunculated accessory hepatic lobe: differential diagnosis of projectile vomiting in a neonate. J Perinat Med. 2006; 34:248-9. 